\title{
Determining the Rating of Ukrainian Banks on the Risk of Legalization of Illegally Obtained Income
}

\author{
SeRHII V. LyeONovi, OlHa V. KUZMENKo ${ }^{i i}$, SERHII V.MYNenKo ${ }^{i i i}$, \\ ALEKSY S. KWILINSKi iv, OLEKSII V. LyULYOV
}

\begin{abstract}
The article examines a scientific and methodological approach about the rating of banks on the risk of money laundering. A sample of 18 indicators of 65 Ukrainian banks in 2019 was selected. The relative indicators that characterize the risk of using the bank's operations to legalize i illegal income are considered. Logically, the indicators are divided into three parts. The first group of indicators characterizes the quantity and quality of the bank's compliance with current legislation of Ukraine in the field of financial monitoring. The second group of indicators reflects the size of cash turnover in the bank, which is a characteristic of the bank's participation as a conversion center. The third group of indicators characterizes the bank's involvement in international income laundering cycles, considering transactions in countries offshore zones and dubious transactions without explicit confirmation by a foreign trade contract. The study of input data on multicollinearity was carried out, based on which 5 indicators that are collinear with others were excluded. Normalization of the input data set based on nonlinear normalization is carried out. The weights of each indicator are calculated based on the principal component's method. The optimal number of factors was determined based on the percentage of the variance explained by each factor and the graph of the scree plot. Minkowski metric was used to construct the integral index. Based on the integrated indicator, the rating of banks on the risk of money laundering was formed. The verbal-numerical Harrington scale provided a qualitative characterization of the risk of using bank operations to legalize illicit income. MS Office Excel software and Correlations of the statistical package STATISTICA 10 were used for calculations.
\end{abstract}

Key words: Anti-money laundering, the rating of banks, on the risk of legalization, integral indicator, Minkowski metric.

УДК 336.711.011:[343.9.024:336.7](477)

JEL Codes: C01, C15, C58, G21

Introduction. Nowadays Ukraine as well as the world in the conditions of globalization of social and economic relations society faces a problem of legalization of the illegal incomes. Complicating, international and national economic relations are accompanied by growth and integration of financial flows. Criminals use these processes trying to legalize illegall obtained income. According to the latest estimates of the United Nations Office on Drugs and Crime, the amount of legalized funds each year is from 2 to $5 \%$ of world GDP, or it is from 800 billion to 2 trillion US dollars [26].

Problem statement. This problem has been came up in national and foreign literature. Ukrainian scientists: O. Utkina [27], A. Boyko [2], Dmytrov S., Medvid T. [5] V. Levchenko [14], Molotok I. [17, 18], Goncharenko T., Lopa L. [9], Buriak An., Artemenko Al. [3], Dudchenko V. [7] and others. Among foreigners this issue was dealt with Subeh, M. A. [23],

${ }^{i}$ Serhii V. Lyeonov, Dr.Sc. (Economics), Professor, Department of Economic Cybernetics, Sumy State University;

${ }^{i i}$ Olha V. Kuzmenko, Dr.Sc. (Economics), Professor, Department of Economic Cybernetics, Sumy State University;

iii Serhii V. Mynenko, PhD student, Department of Economic Cybernetics, Sumy State University;

${ }^{i v}$ Aleksy S. Kwilinski, Dr.Sc. (Economics), Professor, Department of Marketing, Sumy State University;

${ }^{v}$ Oleksii V. Lyulyov, Dr.Sc. (Economics), Associate Professor, Department of Marketing, Sumy State University.

(C) S. V. Lyeonov, O. V. Kuzmenko, S. V. Mynenko, A. S. Kwilinski, O. V. Lyulyov, 2020.

https://doi.org/10.21272/mer.2020.89.03 
С. В. Лсонов, О. В. Кузьменко, С. В. Миненко, О. С. Квілінський, О. В. Люльов.

Визначення рейтингу банків України за ризиком легалізації доходів, отриманих незаконним шляхом

M. Naheem [19], D. Cash [4], M. Riccardi, R. Milani, D. Camerini [22], Giebe C., Hammerström L., Zwerenz D. [8], Islam S. T., Khan M. Y. H. [10], Mehdi B. [16] and others.

Despite the significant presentation of this topic in the literature, the aspect of the characteristics of banks in accordance with the risk of involving them in the legalization of illegal income remains studied. According to the State Financial Monitoring Service, in the second quarter of 2020, 1.037 .502 reports were submitted to the service on suspicion of legalization of illegal obtained income, of which $98.95 \%$ were from banks. [25]. It is necessary to know which banks have a high risk of using their operations to legalize illegal obtained income: banks, to avoid costs in the form of sanctions from the state and increase their own reputation, state regulators to improve the national system to combat money laundering, reduce it volumes and increase the level of economic security of the state.

The purpose of the work is to rate banks on the risk of money laundering.

Results of the research. Data on the activities of 65 Ukrainian banks in 2019 were selected for the study. Data obtained on request from the National Bank of Ukraine and summarized to 18 indicators.

These indicators include: $I_{1}$ - the share of financial transactions that have signs of legalization of income from internal financial monitoring; $I_{2}$ - share of financial transactions in respect of which it was decided not to send to the State Financial Monitoring Service in all financial transactions that were registered on the basis of internal financial monitoring; $I_{3}$ - the share of income in the form of commissions from settlement and cash operations, which falls on one customer bank; $I_{4}$ - the total number of violations by the bank of the Resolutions of the Board of the National Bank of Ukraine; $I_{5}$ - the number of violations of the Law of Ukraine "The Prevention and Counteraction to Legalization (Laundering) of Proceeds from Crime, Financing of Terrorism and Financing of the Proliferation of Weapons of Mass Destruction”; $I_{6}$ - the number of violations of the Law of Ukraine "Banks and Banking"; $I_{7}$ - the share of customers who did not carry out financial transactions, which is per customer of the bank; $I_{8}-$ the share of cash issued with the purpose of purchasing agricultural products, issuing cash from accounts on deposits of individuals and issuing for other purposes, which is per unit of the total amount of cash issued; $I_{9}$ - the amount of cash issued for the purchase of agricultural products, which is per customer of the bank; $I_{10}$ - the amount of cash issued from accounts on deposits of individuals, which is per customer of the bank; $I_{11}$ - the amount of cash issued for other purposes, which is per customer of the bank; $I_{12}$ - share of cash credits in the total amount of cash receipts; $I_{13}$ - share of non- cash credits in the total amount of receipts; $I_{14}$ - share of cash expenditures on deposits of individuals from the total amount of expenditures of individuals; $I_{15}$ - number of performed foreign currency transfer operations to the country belonging to the offshore zone; $I_{16}$ - the amount of foreign currency transfer operations to a country belonging to the offshore zone; $I_{17}$ - number of foreign currency transfer operations abroad without a foreign trade contract; $I_{18}$ - the amount of transfers abroad of foreign currency, which was made without a foreign economic contract.

These indicators characterized the activities of the bank in terms of the characteristics of the risk of money laundering. Thus, indicators $I_{1}-I_{7}$ characterized the quantity and quality of compliance by the bank with the current legislation of Ukraine in the field of financial monitoring. Indicators $I_{8}-I_{14}$ - reflect the size of cash turnover in the bank, which is a characteristic of the bank's participation as a conversion center. Other indicators I15 - I18 characterize the involvement of the bank in international cycles of money laundering, considering transactions in countries - offshore zones and dubious transactions without explicit confirmation by a foreign trade contract $[13,15,21,29]$.

To achieve this goal, we propose to build an integrated indicator of the characteristics of the risk of legalization. 
Serhii V. Lyeonov, Olha V. Kuzmenko, Serhii V. Mynenko, Aleksy S. Kwilinski, Oleksii V. Lyulyov. Determining the Rating of Ukrainian Banks on the Risk of Legalization of Illegally Obtained Income

At the first stage the research of multicollinearity between input indicators is carried out. To do this, you must calculate the linear correlations of Pearson's correlation by the formula:

$$
r=\frac{\overline{x * y}-\bar{x} * \bar{y}}{\sigma_{x} * \sigma_{y}} \mathrm{r}=\frac{\overline{\mathrm{x}^{*} \mathrm{y}}-\overline{\mathrm{x}}^{*} \overline{\mathrm{y}}}{\sigma_{\mathrm{x}}{ }^{*} \sigma_{\mathrm{y}}}
$$

where $\mathrm{r}$ - Pearson's linear correlation coefficient;

$x$ - the first indicator;

$y$ - the second indicator;

$\sigma_{x}$ - the standard deviation of the first indicator;

$\sigma_{y}$ - the standard deviation of the second indicator;

$\overline{x * y}$ - the average value of the product of the indicators;

$\bar{x}$ and $\bar{y}$ - average values of the first and second indicators.

If there are indicators that are related (have the same effect on the result), the correlation coefficient for which will be $r>0.9$. It is necessary to exclude such indicators from further analysis [6].

In the second stage, the data is normalized. Since the input indicators have different dimensions and units, it is necessary to reduce them to a scale $[0 ; 1]$. The obtained values will be comparable and suitable for constructing an integrated indicator.

To achieve this goal, it is proposed to use nonlinear normalization, which has the formula:

$$
\tilde{I_{l j}}=\left(1+e^{\frac{\overline{I_{j}}-I_{i j}}{\sigma I j}}\right)^{-1}
$$

where $\tilde{I_{\imath j}}$ - normalized value $i$ - bank of $j$ - indicator $I$;

$\bar{I}$ - average value of $j$ - indicator $I$;

$I_{i j}$-value $i$ - bank of $j$ - indicator $I$;

$\sigma_{I_{j}}-$ standard deviation $j$ - indicator $I$.

The third stage is to determine the weights for the indicators. At this stage, it is proposed to use the principal components method to calculate the weights of integrated risk assessment of the use of banks to legalize illegally obtained income. To implement this stage, it is proposed to use the tools of the statistical package Statistica 10 "Statistica, Multivariate Exploratory Techniques, Principal Components \& Classification Analysis”. The calculation of weights will consist of the following sequence of actions [28].

3.1. Tables of eigenvalues of factors and factor loads are calculated, and a graph of scree plot.

3.2. Based on the analysis of the tables of power values and the graph of the rocky osip, the optimal number of relevant factors is adopted. The cumulative amount of the variance of the reverse factors is more than $70 \%$.

3.3. The weights for each indicator are calculated based on the variances of the influence of factors and factor loads using the weighted average. The general formula of the average (3) takes the form (4).

$$
\bar{x}=\frac{\sum_{i=1}^{n} x_{i} * f_{i}}{\sum_{i=1}^{n} f_{i}}
$$

where $\bar{x}$ - the average value of the indicator $x$;

$x_{i}-i$ - Te indicator value $x, i=1 . . n$;

$f_{i}-i$ - the value of the frequency of the indicator $x, i=1 . . n$. 


$$
w_{j}=\frac{\sum_{i=1}^{n} F_{j i} * \sigma_{i}^{2}}{\sum_{i=1}^{n} \sigma_{i}^{2}}
$$

where $w_{j}$ - weighting factor of $\mathrm{j}$ - indicator;

$F_{j i}-j$ - те the value of the factor load of the indicator of $i$ - factor, $i=1 . . n$;

$\sigma_{i}^{2}$ - the value of the variance of $i$ - factor, $i=1 . . n$;

After calculating the weights at the fourth stage, an integrated indicator is calculated, which provides a rating assessment of the level of risk of the bank's involvement in the legalization of illegally obtained income.

It is proposed to calculate the integral using the Minkowski metric, which is used to calculate the distance between points in Euclidean space and is a corresponding generalization of Euclidean space. In general, Minkowski metric has the form (5) [12]:

$$
\mathrm{F}\left(\mathrm{x}_{\mathrm{i}}\right)=1-\sqrt{\sum_{\mathrm{j}=1}^{\mathrm{k}} \omega_{\mathrm{j}} \mid 1-\frac{x_{i j}}{\left.\max _{j}\right|^{2}+\sum_{\mathrm{j}=\mathrm{k}+1}^{\mathrm{n}} \omega_{\mathrm{j}}\left|1-\frac{\min _{j} x}{x_{i j}}\right|^{2}}}
$$

where $\mathrm{F}\left(\mathrm{x}_{\mathrm{i}}\right)$ - the value of the integrated indicator;

$x_{i j}-i$ - Te the value of $j$ - indicator, $j=1 . . k$;

$\omega_{j}$ - weighting factor of $j$ - indicator.

Calculated according to Formula 5, the integrated indicator considers both indicators of stimulants (weighing the maximum value of the indicator) and indicators of disincentives (the ratio of the minimum value of the indicator to the value of the indicator). Since in our case all indicators are disincentives, and the normalization of values has already been carried out, the formula of the integrated indicator of the rating of the level of risk of the bank's involvement in the legalization of illegally obtained income takes the form (6):

$$
I_{i}=1-\sqrt{\sum_{\mathrm{j}=1}^{\mathrm{k}} \mathrm{w}_{\mathrm{j}}\left|1-\widetilde{\Pi}_{\mathrm{j}}\right|^{2}}
$$

$\mathrm{w} I_{i}$ - the value of the integrated indicator;

$\widetilde{\Pi}_{j}-$ normalized by the formula $1.13 i$ - value $j$-indicator, $j=1 . . k$;

$w_{j}$ - weighting factor $j$ - indicator, calculated by Formula 4 .

In the sixth stage, a rating from 1 to 65 is built from the best to the worst bank, according to the risk of using the bank's operations to legalize illegally obtained income. To do this, it is advisable to use the following formula:

$$
R_{i}=\left\{\begin{array}{r}
\text { 1, if } I_{i 1}=\max _{i} I_{i} \\
\text { 2, if } I_{i 2}=\max _{i}\left\{\begin{array}{c}
I_{i r} ; \\
-\max _{i} I_{i 1}
\end{array}\right\} \\
3, \text { if } I_{i 3}=\max _{i}\left\{\begin{array}{c}
I_{i r} ; \\
-\max _{i} I_{i 1}, \\
-\max _{i} I_{i 2}
\end{array}\right\} \\
\cdots \\
n, \text { if } I_{i n}=\max _{i}\left\{\begin{array}{c}
I_{i r} ; \\
-\max _{i} I_{i 1}, \\
\cdots, \\
-\max _{i} I_{i n-1}
\end{array}\right\}
\end{array}\right.
$$


Serhii V. Lyeonov, Olha V. Kuzmenko, Serhii V. Mynenko, Aleksy S. Kwilinski, Oleksii V. Lyulyov. Determining the Rating of Ukrainian Banks on the Risk of Legalization of Illegally Obtained Income

Calculations were performed using MS Excel and statistical package STATISTICA 10. The input data are 18 indicators, which are shown in Table 1.

Table 1.

Input indicators in 2019

\begin{tabular}{|c|c|c|c|c|c|c|c|c|c|c|}
\hline $\begin{array}{c}\text { № of the } \\
\text { bank }\end{array}$ & $\Pi_{1}$ & $\Pi_{2}$ & $\Pi_{3}$ & $\Pi_{4}$ & $\Pi_{5}$ & $\ldots$ & $\Pi_{15}$ & $\Pi_{16}$ & $\Pi_{17}$ & $\Pi_{18}$ \\
\hline A & 1 & 2 & 3 & 4 & 5 & $\ldots$ & 15 & 16 & 17 & 18 \\
\hline 1 & 0,16 & 0,98 & 0,05 & 16,00 & 18,00 & $\ldots$ & 0,00 & 0,00 & 97,00 & 12964,00 \\
\hline 2 & 0,43 & 0,17 & 0,00 & 77,00 & 37,00 & $\ldots$ & 0,00 & 0,00 & 0,00 & 0,00 \\
\hline 3 & 0,17 & 0,03 & 0,11 & 20,00 & 11,00 & $\ldots$ & 1,00 & 43,37 & 198,00 & 33430,00 \\
\hline 4 & 0,23 & 0,01 & 0,05 & 30,00 & 32,00 & $\ldots$ & 0,00 & 0,00 & 16,00 & 343,00 \\
\hline 5 & 0,29 & 0,76 & 0,07 & 6,00 & 0,00 & $\ldots$ & 1,00 & 120,00 & 139,00 & 23195,00 \\
\hline 6 & 0,26 & 0,00 & 0,10 & 0,00 & 0,00 & $\ldots$ & 1,00 & 65,00 & 92,00 & 209733,00 \\
\hline$\ldots$ & $\ldots$ & $\ldots$ & $\ldots$ & $\ldots$ & $\ldots$ & $\ldots$ & $\ldots$ & $\ldots$ & $\ldots$ & $\ldots$ \\
\hline 55 & 0,37 & 0,63 & 4,20 & 1,00 & 1,00 & $\ldots$ & 0,00 & 0,00 & 5,00 & 6660,00 \\
\hline 56 & 0,12 & 0,00 & 0,65 & 0,00 & 0,00 & $\ldots$ & 0,00 & 0,00 & 19,00 & 5132,00 \\
\hline 57 & 0,34 & 0,99 & 0,03 & 0,00 & 0,00 & $\ldots$ & 0,00 & 0,00 & 2,00 & 292,00 \\
\hline 58 & 0,85 & 0,00 & 0,72 & 0,00 & 0,00 & $\ldots$ & 0,00 & 0,00 & 0,00 & 0,00 \\
\hline 59 & 0,49 & 0,01 & 0,04 & 0,00 & 0,00 & $\ldots$ & 0,00 & 0,00 & 0,00 & 0,00 \\
\hline 60 & 0,00 & 0,00 & 0,73 & 0,00 & 0,00 & $\ldots$ & 0,00 & 0,00 & 0,00 & 0,00 \\
\hline 61 & 0,11 & 0,15 & 0,12 & 0,00 & 0,00 & $\ldots$ & 0,00 & 0,00 & 0,00 & 0,00 \\
\hline 62 & 0,02 & 1,00 & 0,66 & 2,00 & 0,00 & $\ldots$ & 0,00 & 0,00 & 0,00 & 0,00 \\
\hline 63 & 0,00 & 1,00 & 0,07 & 0,00 & 0,00 & $\ldots$ & 0,00 & 0,00 & 0,00 & 0,00 \\
\hline 64 & 0,26 & 0,17 & 0,86 & 0,00 & 0,00 & $\ldots$ & 0,00 & 0,00 & 5,00 & 3911,00 \\
\hline 65 & 0,00 & 1,00 & 0,29 & 6,00 & 0,00 & $\ldots$ & 0,00 & 0,00 & 0,00 & 0,00 \\
\hline
\end{tabular}

Moving on to the first stage, the assessment of multicollinearity between indicators, we will use the tool of the statistical package Statistica 10 "Correlations". The result is shown in Table 2.

Table 2 shows that a close and statistically significant (highlighted in red) relationship is between the indicators $I_{1}$ та $I_{2},{ }_{1}$ та $I_{8}, I_{1}$ та $I_{10}, I_{1}$ та $I_{12}, I_{2}$ та $I_{12}, I_{4}$ та $I_{5}, I_{7}$ та $I_{8}, I_{7}$ та $I_{12}, I_{7}$ та $I_{14}, I_{8}$ та $I_{12}$, $I_{8}$ та $I_{14}, I_{12}$ та $I_{14}, I_{15}$ та $I_{16}$.

Table 2

Correlated matrix *

\begin{tabular}{|c|c|c|c|c|c|c|c|c|c|c|c|c|c|c|c|c|c|c|}
\hline & $I_{1}$ & $I_{2}$ & $I_{3}$ & $I_{4}$ & $I_{5}$ & $I_{6}$ & $I_{7}$ & $I_{8}$ & $I_{9}$ & $I_{10}$ & $I_{11}$ & $I_{12}$ & $I_{13}$ & $I_{14}$ & $I_{15}$ & $I_{16}$ & $I_{17}$ & $I_{18}$ \\
\hline$I_{1}$ & 1,00 & 0,86 & 0,28 & 0,01 & 0,21 & 0,53 & \begin{tabular}{|l|}
0,69 \\
\end{tabular} & & 0,11 & & 0,04 & & 0,17 & \begin{tabular}{|l|}
0,79 \\
\end{tabular} & & $-0,05$ & & \\
\hline$I_{2}$ & 86 & 00 & 0,44 & $-0,05$ & 0,13 & 0,44 & 0,63 & 6 & 0,01 & & 0,04 & 0,81 &, 34 & 0,73 & 0,05 & 0,08 & 0,02 & \\
\hline$I_{3}$ & 28 & 44 & 00 & \begin{tabular}{|l|}
$-0,08$ \\
\end{tabular} & 0,03 & 10 & 21 & 41 & 10 & 0,31 & 0,06 & ,34 & 24 & 24 & $-0,09$ & $-0,08$ & 0,52 & 0,5 \\
\hline$I_{4}$ & 01 & 0,05 & $-0,08$ & 1,00 & 0,81 & 0,18 & 0,02 & 0,01 & $-0,03$ & $-0,04$ & $-0,03$ & $-0,01$ & & 03 & $-0,02$ & $-0,02$ & 10 & 0,0 \\
\hline$I_{5}$ & & 13 & $-0,03$ & 0,81 & 00 &, 42 & \begin{tabular}{l|}
0,12 \\
\end{tabular} & & 000 & 0,12 & $-0,09$ & 0,24 & & 22 & 0,04 & 0,03 & & \\
\hline$I_{6}$ & 53 & 44 & 0,10 & 0,18 &, 42 & 1,00 & 38 &, 47 & $-0,01$ & 45 & $-0,02$ & 0,51 & 0,08 & 46 & $-0,02$ & $-0,02$ & $-0,04$ & 0,0 \\
\hline$I_{7}$ & & 63 & 21 & $-0,02$ & 12 & ,38 & & & 0,10 & 71 & 0,10 & 83 & & 91 & $-0,03$ & & & \\
\hline$I_{8}$ & 83 & ,76 & 0,41 & 0,01 & 0,26 & 0,47 & 0,83 & 1,00 & 0,06 & 0,79 & 0,05 & 0,96 & 0,37 & 88 & 0,01 & 0,03 & 0,08 & 0,00 \\
\hline$I_{9}$ & & 01 & & $-0,03$ & $-0,09$ & $-0,01$ & & & 00 & & ,31 & & & 11 & $-0,07$ & $-0,06$ & $-0,06$ & 0,0 \\
\hline$I_{10}$ & 86 & 75 & 1 & $-0,04$ & 0,12 & 0,45 & 1 & & 0,1 & & 0,16 & 0,79 & 0,3 &, 76 & $-0,0$ & $-0,06$ & 0, & 0 \\
\hline$I_{11}$ & 04 & 04 & 0,06 & $-0,03$ & $-0,09$ & \begin{tabular}{|l|}
$-0,02$ \\
\end{tabular} & 0,10 & 05 & 0,31 & 6 & 1,00 & 08 & 1 & 19 & $-0,08$ & $-0,07$ & 0,0 & 0, \\
\hline$I_{12}$ & & & & 0,01 & 0,24 & 51 & & & & & & & & & 0,03 & 0,05 & & \\
\hline$I_{13}$ & 17 & 34 & 24 & 0,14 & 0,14 & 0,08 & 57 & 37 & 0,04 & 37 & 0,21 & 25 & 1,00 & 0,46 & $-0,10$ & $-0,08$ & 0,13 & 0,0 \\
\hline$I_{14}$ & 79 & 73 & 0,24 & 0,03 & 0,22 & 0,46 & 0,91 & 88 & 0,11 & 0,76 & 0,19 & 0,92 & 0,46 & 1,00 & $-0,04$ & 0 & 0,0 & 0,0 \\
\hline$I_{15}$ & $-0,06$ & 0,05 & $-0,09$ & $-0,02$ & 0,04 & $-0,02$ & \begin{tabular}{|l|}
$-0,03$ \\
\end{tabular} & 0,01 & $-0,0$ & 00 & $-0,08$ & 0,03 & -0, & & 1,00 & 0,96 & & 0,1 \\
\hline$I_{16}$ & $-0,05$ & 0,08 & $-0,08$ & $-0,02$ & 0,03 & $-0,02$ & \begin{tabular}{|l|}
$-0,01$ \\
\end{tabular} & 0,03 & $-0,06$ & 0 & $-0,07$ & 0,05 & $-0,08$ & & 0,96 & 0 & 0,13 & 0,1 \\
\hline$I_{17}$ & $-0,05$ & \begin{tabular}{|l|}
0,02 \\
\end{tabular} & & 0,10 & 0,11 & $-0,04$ & 0,02 & 0,08 & $-0,06$ & & $-0,09$ & 0,02 & & & 0,15 & & & 0,7 \\
\hline & $-0,05$ & $-0,01$ & 0,54 & $-0,05$ & $-0,07$ & $-0,07$ & $-0,04$ & 0,00 & $-0,07$ & 006 & $-0,08$ & $-0,03$ & 0,05 & 005 & 0,14 & 0,11 & 0,76 & 1,00 \\
\hline
\end{tabular}


С. В. Лсонов, О. В. Кузьменко, С. В. Миненко, О. С. Квілінський, О. В. Люльов.

Визначення рейтингу банків України за ризиком легалізації доходів, отриманих незаконним шляхом

To get rid of multicollinearity, we will remove the indicator from the study $I_{2}$ - share of financial transactions in respect of which it was decided not to send to the State Financial Monitoring Service in all financial transactions that were registered on the basis of internal financial monitoring, $I_{4}$ - the total number of violations by the bank of the Resolutions of the Board of the National Bank of Ukraine, $I_{7}$ the share of customers who did not carry out financial transactions, which is per customer of the bank, $I_{8}$ - the share of cash issued with the purpose of purchasing agricultural products, issuing cash from accounts on deposits of individuals and issuing for other purposes, which is per unit of the total amount of cash issued and $I_{15}$ - the number of foreign currency transfer transactions to a country belonging to an offshore zone.

Applying Formula 2 we obtain the following normalized values of indicators that are used in subsequent calculations (Table 3).

Table 3

Normalized values of indicators

\begin{tabular}{|c|c|c|c|c|c|c|c|c|c|c|c|c|c|}
\hline № & $\widetilde{I_{1}}$ & $\widetilde{I_{3}}$ & $\widetilde{I_{5}}$ & $\widetilde{I_{6}}$ & $\widetilde{I_{9}}$ & $\widetilde{I_{10}}$ & $\widetilde{I_{11}}$ & $\widetilde{I_{12}}$ & $\widetilde{I_{13}}$ & $\widetilde{I_{14}}$ & $\widetilde{I_{16}}$ & $\widetilde{I_{17}}$ & $\widetilde{I_{18}}$ \\
\hline $\mathrm{A}$ & 1 & 2 & 3 & 4 & 5 & 6 & 7 & 8 & 9 & 10 & 11 & 12 & 13 \\
\hline 1 & 0,471 & 0,415 & 0,857 & 0,434 & 0,435 & 0,441 & 0,425 & 0,497 & 0,580 & 0,421 & 0,436 & 0,933 & 0,573 \\
\hline 2 & 0,518 & 0,406 & 0,963 & 0,823 & 0,435 & 0,440 & 0,426 & 0,453 & 0,574 & 0,646 & 0,436 & 0,402 & 0,421 \\
\hline 3 & 0,454 & 0,416 & 0,590 & 0,487 & 0,437 & 0,441 & 0,425 & 0,440 & 0,435 & 0,409 & 0,760 & 0,954 & 0,635 \\
\hline 4 & 0,527 & 0,421 & 0,997 & 0,628 & 0,436 & 0,442 & 0,427 & 0,568 & 0,782 & 0,483 & 0,436 & 0,604 & 0,427 \\
\hline 5 & 0,450 & 0,409 & 0,410 & 0,434 & 0,436 & 0,440 & 0,424 & 0,389 & 0,391 & 0,382 & 0,842 & 0,689 & 0,495 \\
\hline 6 & 0,461 & 0,413 & 0,410 & 0,434 & 0,435 & 0,440 & 0,424 & 0,434 & 0,403 & 0,423 & 0,826 & 0,725 & 0,988 \\
\hline$\ldots$ & $\ldots$ & $\ldots$ & $\ldots$ & $\ldots$ & $\ldots$ & $\ldots$ & $\ldots$ & $\ldots$ & $\ldots$ & $\ldots$ & $\ldots$ & $\ldots$ & $\ldots$ \\
\hline 55 & 0,454 & 0,603 & 0,418 & 0,452 & 0,436 & 0,568 & 0,470 & 0,393 & 0,371 & 0,381 & 0,436 & 0,411 & 0,441 \\
\hline 56 & 0,438 & 0,435 & 0,410 & 0,434 & 0,439 & 0,458 & 0,494 & 0,402 & 0,346 & 0,398 & 0,436 & 0,438 & 0,436 \\
\hline 57 & 0,452 & 0,407 & 0,410 & 0,434 & 0,440 & 0,440 & 0,424 & 0,390 & 0,383 & 0,382 & 0,436 & 0,406 & 0,422 \\
\hline 58 & 0,699 & 0,576 & 0,410 & 0,465 & 0,996 & 0,446 & 0,446 & 0,658 & 0,351 & 0,531 & 0,436 & 0,402 & 0,421 \\
\hline 59 & 0,479 & 0,408 & 0,410 & 0,434 & 0,436 & 0,442 & 0,430 & 0,428 & 0,368 & 0,415 & 0,436 & 0,402 & 0,421 \\
\hline 60 & 0,430 & 0,467 & 0,410 & 0,434 & 0,435 & 0,470 & 0,783 & 0,420 & 0,432 & 0,485 & 0,436 & 0,402 & 0,421 \\
\hline 61 & 0,440 & 0,413 & 0,410 & 0,434 & 0,437 & 0,443 & 0,426 & 0,417 & 0,370 & 0,407 & 0,436 & 0,402 & 0,421 \\
\hline 62 & 0,432 & 0,453 & 0,410 & 0,434 & 0,435 & 0,444 & 0,441 & 0,434 & 0,356 & 0,395 & 0,436 & 0,402 & 0,421 \\
\hline 63 & 0,430 & 0,414 & 0,410 & 0,434 & 0,435 & 0,440 & 0,424 & 0,485 & 0,413 & 0,417 & 0,436 & 0,402 & 0,421 \\
\hline 64 & 0,436 & 0,420 & 0,410 & 0,434 & 0,437 & 0,448 & 0,430 & 0,365 & 0,343 & 0,372 & 0,436 & 0,405 & 0,425 \\
\hline 65 & 0,430 & 0,426 & 0,410 & 0,434 & 0,435 & 0,440 & 0,424 & 0,344 & 0,601 & 0,367 & 0,436 & 0,402 & 0,421 \\
\hline
\end{tabular}

At the third stage we apply to the data from table 3 the tool "Statistica, Multivariate Exploratory Techniques, Principal Components \& Classification Analysis”, we get the table of eigenvalues of factors (Table 4), the graph of scree plot (Figure 1) and the table of values of factor loadings (Table 5).

Analyzing Table 4 we see that the first 5 factors in total characterize the $76.926 \%$ variance of the input data (column 4). Based on this, we conclude that the optimal number of factors to characterize the level of risk of money laundering are the first 5 factors. This conclusion is confirmed by the analysis of the graph of the scree, which shows that starting from factor 5 , the curve begins to change its tendency to a sharp decline, which is a criterion for optimality in the schedule of the scree [20].

The table of factor loadings (Table 5) contains values which are indicators of influence of each indicator on the corresponding factor. In the future, the first 5 columns will be used, which correspond to the optimal number of factors that we take for analysis in the future.

Applying for the values of variances from table 4 and the values of factor loads from table 5 , Formula 4, we obtain a vector of weights for the integrated indicator of the rating of the risk of bank involvement in the legalization of illegally obtained income. The results of the calculations are shown in Table 6. 
Serhii V. Lyeonov, Olha V. Kuzmenko, Serhii V. Mynenko, Aleksy S. Kwilinski, Oleksii V. Lyulyov. Determining the Rating of Ukrainian Banks on the Risk of Legalization of Illegally Obtained Income

Table 4

Table of eigenvalues of the calculated factors

\begin{tabular}{|c|c|c|c|c|}
\hline Value number & Eigenvalue & \% Total variance & Cumulative Eigenvalue & Cumulative \% \\
\hline A & 1 & 2 & 3 & 4 \\
\hline 1 & 4,220 & 32,458 & 4,220 & 32,458 \\
\hline 2 & 2,236 & 17,199 & 6,455 & 49,658 \\
\hline 3 & 1,522 & 11,708 & 7,978 & 61,366 \\
\hline 4 & 1,037 & 7,976 & 9,014 & 79,342 \\
\hline 5 & 0,986 & 7,585 & 10,000 & 83,926 \\
\hline 6 & 0,909 & 6,990 & 10,909 & 88,817 \\
\hline 7 & 0,637 & 4,901 & 11,546 & 92,356 \\
\hline 8 & 0,460 & 3,539 & 12,006 & 95,391 \\
\hline 9 & 0,394 & 3,034 & 12,401 & 97,507 \\
\hline 10 & 0,275 & 2,116 & 12,676 & 99,129 \\
\hline 11 & 0,211 & 1,622 & 12,887 & 99,774 \\
\hline 12 & 0,084 & 0,646 & 12,971 & 100,000 \\
\hline 13 & 0,029 & 0,226 & 13,000 & \\
\hline
\end{tabular}

Eigenvalues of correlation matrix

Active variables only

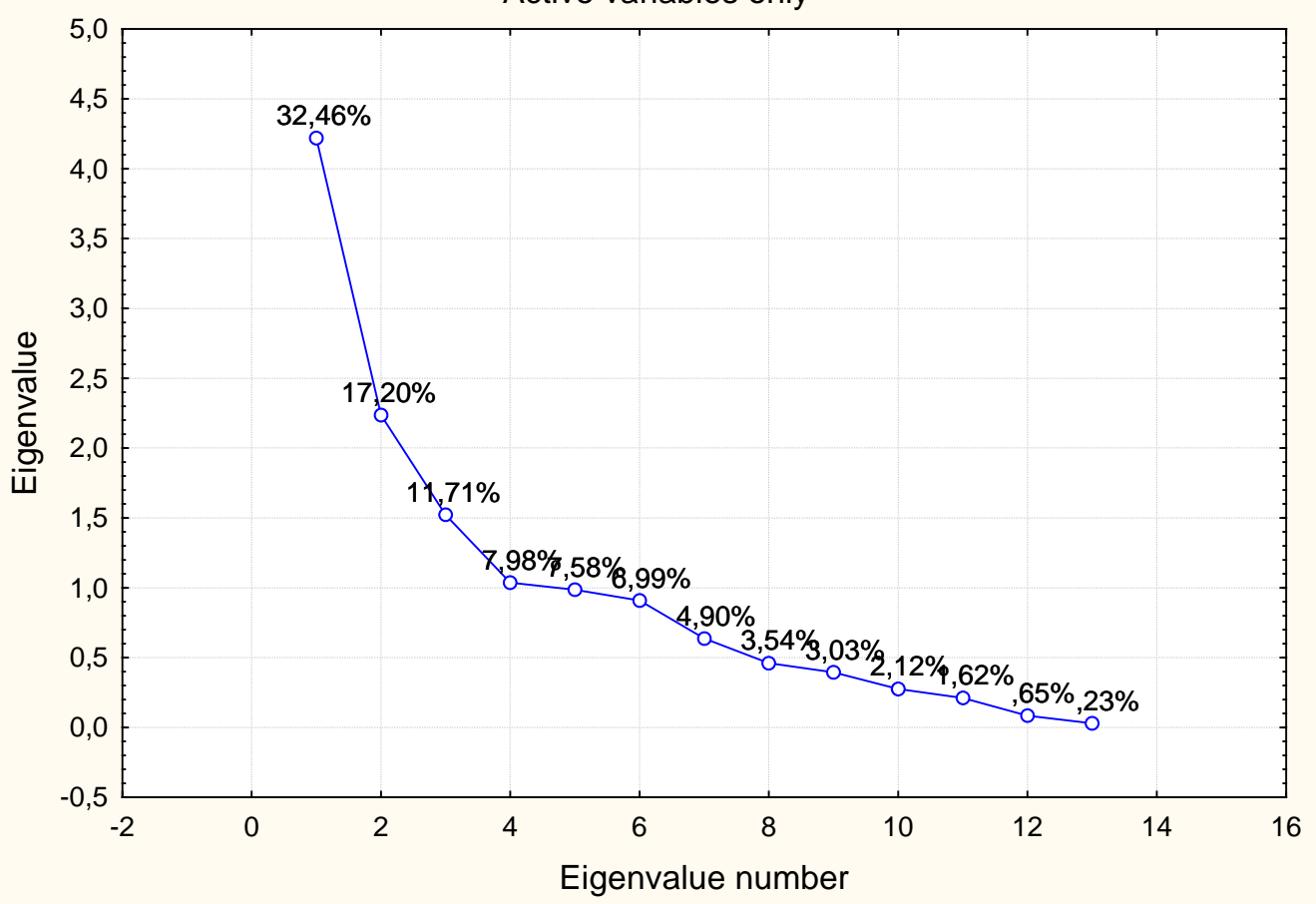

Figure 1. Graph of scree plot 
С. В. Леонов, О. В. Кузьменко, С. В. Миненко, О. С. Квілінський, О. В. Люльов.

Визначення рейтингу банків України за ризиком легалізації доходів, отриманих незаконним шляхом

Table 5

Table of factor loads

\begin{tabular}{|c|c|c|c|c|c|c|c|c|c|c|c|c|c|}
\hline \multirow{2}{*}{ Variable } & \multicolumn{13}{|c|}{ Factor } \\
\hline & 1 & 2 & 3 & 4 & 5 & 6 & 7 & 8 & 9 & 10 & 11 & 12 & 13 \\
\hline$I_{1}$ & 0,1959 & 0039 & 0047 &, 0410 & 0,0320 & 0,0004 & 0,0002 & & 0,0008 & 0,0664 & & & \\
\hline$I_{3}$ & 0372 & 2217 & 0315 & 0001 & 0,0454 & 0,0056 & 0003 & &, 5910 & & & & \\
\hline$I_{5}$ & & & & & & & & & & & & & \\
\hline$I_{6}$ & 904 & 0076 & 013 & 074 & 0,0007 & 0,1335 & 0,0992 & 5376 & 0,0098 & 0,0083 & 0,0039 & 0,0001 & 0,0000 \\
\hline$I_{9}$ & & & 431 & & 398 & & 0,2801 & & & & & & 0007 \\
\hline$I_{10}$ & & & & & & & & & & & & & \\
\hline$I_{11}$ & 071 & 0,0063 & 3099 & & 0, & 0,0073 & 0,4655 & 268 & 0,0005 & 002 & & & 0,0012 \\
\hline$I_{12}$ & & & & & & 006 & 0,0022 & & & & & & 0,5749 \\
\hline$I_{13}$ & 4442 & 0,0100 & 0501 & & 0,0712 & 0,2141 & 0,1200 & & 0,0009 & 0044 & 001 & 0,0536 & 0,0146 \\
\hline$I_{14}$ & 1984 & 0,0022 & 0,0012 & 0,0000 & 0,0030 & 0,0278 & 0,0026 & 0,0217 & 0,0760 & 0,2211 & 0,0432 & 0,0809 & \\
\hline$I_{16}$ & 0,0006 & 0,0085 & 0,0570 & 0,3117 & 0,4871 & 0,0697 & 0,0008 & 0,0180 & 0,0391 & 0,0020 & 0,0000 & 0,0006 & 0,0048 \\
\hline$I_{17}$ & 0,0005 & 0,3635 & 0,0049 & 0,0042 & 0,0131 & 0,0123 & 0,0000 & 0,0217 & 0,0879 & 0,0134 & 0,4767 & 0,0016 & 0,0001 \\
\hline$I_{18}$ & 0,0000 & 0,3684 & 0,0001 & 0,0054 & 0,0012 & 0,0036 & 0,0159 & 0,0012 & 0,1297 & 0,0798 & 0,3900 & 0,0009 & 0,0041 \\
\hline
\end{tabular}

Table 6

Weights for the integrated indicator of the rating assessment of the level of risk of the bank's involvement in the legalization of illegally obtained income

\begin{tabular}{|c|c|}
\hline Indicator & $w_{j}$ \\
\hline $\mathrm{A}$ & 1 \\
\hline$I_{1}$ & 0,091652 \\
\hline$I_{3}$ & 0,074548 \\
\hline$I_{5}$ & 0,074578 \\
\hline$I_{6}$ & 0,056108 \\
\hline$I_{9}$ & 0,049397 \\
\hline$I_{10}$ & 0,082741 \\
\hline$I_{11}$ & 0,068366 \\
\hline$I_{12}$ & 0,092647 \\
\hline$I_{13}$ & 0,067076 \\
\hline$I_{14}$ & 0,084691 \\
\hline$I_{16}$ & 0,091164 \\
\hline$I_{17}$ & 0,083978 \\
\hline$I_{18}$ & 0,083055 \\
\hline
\end{tabular}

The next step is to develop the integral indicator of the rating assessment of the level of the bank's income before the legalization of income, which was taken out by an illegal way.

The normalized input indicators (Table 3) and the volume of performance (Table 6) Formula 6 , the value of the integral indicator of the rating assessment is considered the risk of the bank's receipt of the illegal income of Tables 7.

Moving to the sixth stage, we apply formula 7 and form a rating list of Ukrainian banks, in accordance with the risk of legalization of income obtained illegally (Table 7 of column A).

Analyzing the obtained results, we note that the best place in the ranking has the bank JSC "BANK ALLIANCE" with a value of 0.6385. By constructing a verbal-numerical Harrington scale for the obtained rating assessment [1] with a step of 0.25 (Table 8), we obtain a qualitative characteristic of the rating assessment of the risk of the bank's involvement in money laundering.

Conclusions and prospects of further research. Top 12 of the banks have the lowest risk of money laundering. These include JSC "BANK ALLIANCE" with a rating of 1, JSC "TASKOMBANK" with a rating of 2, JSC "ASVIO BANK" with a rating of 3, JSC "JSB 
Serhii V. Lyeonov, Olha V. Kuzmenko, Serhii V. Mynenko, Aleksy S. Kwilinski, Oleksii V. Lyulyov. Determining the Rating of Ukrainian Banks on the Risk of Legalization of Illegally Obtained Income

RADABANK” with a rating of 4, and JSC “Citibank” (Ukraine) with a rating of 5, JSC "ProCredit Bank" with a rating of 6, JSC “JSB UKRGASBANK" with a rating of 7, JSC "Idea Bank" with a rating of 8, JSC "Ukreximbank” with a rating of 9, JSC "International Investment Bank" with a rating of 10, JSC CB “PRIVATBANK” with a rating of 11 and PJSC CB “AKORDBANK” with a rating of 12 .

Table 7

Rating assessment of the level of risk of the bank's involvement in the legalization of illegally obtained income

\begin{tabular}{|c|c|c|c|c|c|c|c|c|c|c|c|c|c|c|}
\hline $\mathrm{R}$ & № & $\mathrm{I}$ & $\mathrm{R}$ & № & $\mathrm{I}$ & $\mathrm{R}$ & № & $\mathrm{I}$ & $\mathrm{R}$ & № & $\mathrm{I}$ & $\mathrm{R}$ & № & $\mathrm{I}$ \\
\hline $\mathrm{A}$ & 1 & 2 & $\mathrm{~A}$ & 1 & 2 & $\mathrm{~A}$ & 1 & 2 & $\mathrm{~A}$ & 1 & 2 & $\mathrm{~A}$ & 1 & 2 \\
\hline 1 & 36 & 0,6385 & 14 & 6 & 0,4985 & 27 & 30 & 0,4655 & 40 & 46 & 0,4286 & 53 & 27 & 0,4195 \\
\hline 2 & 26 & 0,6113 & 15 & 7 & 0,4962 & 28 & 14 & 0,4646 & 41 & 31 & 0,4284 & 54 & 41 & 0,4194 \\
\hline 3 & 54 & 0,5640 & 16 & 51 & 0,4957 & 29 & 20 & 0,4616 & 42 & 63 & 0,4282 & 55 & 61 & 0,4193 \\
\hline 4 & 42 & 0,5473 & 17 & 58 & 0,4952 & 30 & 8 & 0,4575 & 43 & 56 & 0,4268 & 56 & 57 & 0,4163 \\
\hline 5 & 12 & 0,5296 & 18 & 28 & 0,4952 & 31 & 15 & 0,4572 & 44 & 44 & 0,4266 & 57 & 11 & 0,4152 \\
\hline 6 & 13 & 0,5230 & 19 & 10 & 0,4874 & 32 & 23 & 0,4569 & 45 & 59 & 0,4241 & 58 & 17 & 0,4150 \\
\hline 7 & 4 & 0,5207 & 20 & 52 & 0,4868 & 33 & 60 & 0,4530 & 46 & 25 & 0,4239 & 59 & 33 & 0,4149 \\
\hline 8 & 16 & 0,5127 & 21 & 9 & 0,4821 & 34 & 37 & 0,4476 & 47 & 45 & 0,4226 & 60 & 48 & 0,4118 \\
\hline 9 & 3 & 0,5094 & 22 & 34 & 0,4812 & 35 & 47 & 0,4467 & 48 & 62 & 0,4222 & 61 & 53 & 0,4117 \\
\hline 10 & 35 & 0,5069 & 23 & 43 & 0,4759 & 36 & 55 & 0,4444 & 49 & 65 & 0,4220 & 62 & 39 & 0,4117 \\
\hline 11 & 1 & 0,5069 & 24 & 19 & 0,4693 & 37 & 32 & 0,4405 & 50 & 40 & 0,4207 & 63 & 64 & 0,4108 \\
\hline 12 & 38 & 0,5040 & 25 & 24 & 0,4667 & 38 & 29 & 0,4312 & 51 & 49 & 0,4205 & 64 & 21 & 0,4086 \\
\hline 13 & 2 & 0,4988 & 26 & 5 & 0,4658 & 39 & 50 & 0,4293 & 52 & 18 & 0,4198 & 65 & 22 & 0,4066 \\
\hline
\end{tabular}

Calculated by the authors. $R$ - rating position, № - bank number, $I$ - value of the indicator

Table 8

Verbal-numerical Harrington scale

\begin{tabular}{|c|c|c|c|}
\hline Interval & Indicator value & Number of banks & Specific weight, \% \\
\hline$[0 ; 0,25)$ & Critical risk & 0 & 0,00 \\
\hline$[0,25 ; 0,5)$ & High risk & 53 & 81,54 \\
\hline$[0,5 ; 0,75)$ & Moderate risk & 12 & 18,46 \\
\hline$[0,75 ; 1]$ & Low risk & 0 & 0,00 \\
\hline
\end{tabular}

According to the study, 12 banks (18.46\%) are rated to have a moderate risk of being used to legalize illegal income. Instead, 53 banks (81.54\%) are rated at high risk of being involved in money laundering. Graphically calculated dependence is shown in Figure 2.

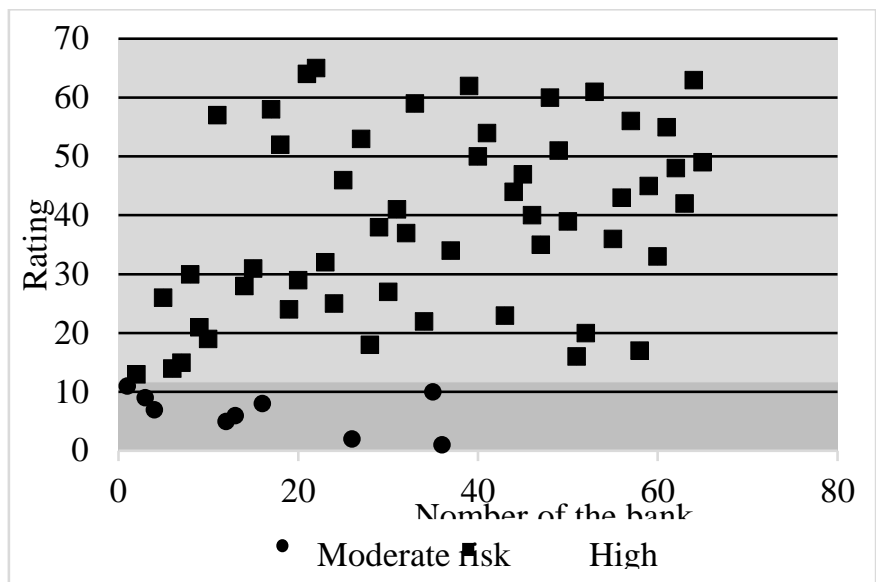

Figure 2. Distribution of banks according to the rating on the risk of money laundering 
С. В. Лсонов, О. В. Кузьменко, С. В. Миненко, О. С. Квілінський, О. В. Люльов.

Визначення рейтингу банків України за ризиком легалізації доходів, отриманих незаконним шляхом

In general, all surveyed banks have either a moderate or high risk of money laundering. This indicates the vulnerability of the banking system of Ukraine to the legalization of illegally obtained income. Which creates prospects for further research in this area namely, the definition of determinants of the impact on the level of risk of money laundering and the development of recommendations to minimize this risk [24]. [24].

Acknowledgment. This work was performed as part of a study funded by the National Research Fund of Ukraine No. 2020.01 / 0185 "Optimization and automation of financial monitoring processes for the growth of information security of Ukraine”.

\section{References}

1. Bezhentseva, T., Aleksandrova, N., Matyus, E. (2018). Formation of system of indicators for evaluation of environmental activities. IOP Conference Series: Materials Science and Engineering, 451. https://doi.org/10.1088/1742- 6596/451/1/012182.

2. Boyko, A. (2019). Systema protydii lehalizatsii kryminalnykh dokhodiv u zabezpechenni ekonomichnoi bezpeky natsionalnoi ekonomiky [The system of counteracting the legalization of criminal income in ensuring the economic security of the national economy]. (Dr. Sc. thesis). Sumy state university, Sumy. Retrieved from https://essuir.sumdu.edu.ua/handle/123456789/75303. [in Ukrainian]

3. Buriak An., Artemenko Al.. (2018). Reputation risk in banking: application for Ukraine. Financial Markets, Institutions and Risks, 2(2), 100- 110. DOI: 10.21272/fmir.2(2).100- 110.2018

4. Cash, D. (2019). Sigma ratings: adapting the credit rating agency model for the anti- money laundering world. Journal of Money Laundering Control, 23(1), 1- 10. https://doi.org/10.1108/JMLC- 06- 20190046.

5. Dmytrov, S., Medvid, T. (2017). An approach to the use of indices- based analysis subject to money laundering and terrorist financing national risk assessment SocioEconomic Challenges, 1(1), 35- 47. http://doi.org/10.21272/sec.2017.1- 04.

6. Druhov, O., Druhova, V., Pakhnenko, O. (2019). The Influence of Financial Innovations on EU Countries Banking Systems Development. Marketing and Management of Innovations, 3, 167- 177. http://doi.org/10.21272/mmi.2019.3- 13

7. Dudchenko, V. (2020). Role of Central Bank Independence in Banking and Financial Stability Ensuring. Financial Markets, Institutions and Risks, 4(2), 115- 121. https://doi.org/10.21272/fmir.4(2).115- 121.2020.

8. Giebe, C., Hammerström, L., Zwerenz, D. (2019). Big Data \& Analytics as a sustainable Customer Loyalty Instrument in Banking and Finance. Financial Markets, Institutions and Risks, 3(4), 74- 88. http://doi.org/10.21272/fmir.3(4).74- 88.2019.

9. Goncharenko, T., Lopa L. (2020). Balance Between Risk And Profit In The Context Of Strategic Management: The Case Of Ukrainian Banks. SocioEconomic Challenges, 4(1), 111- 121. http://doi.org/10.21272/sec.4(1).111- 121.2020.

10. Islam, S.T., Khan, M.Y.H. (2019). Evaluating the changes in the European Banking Regulation MiFID and its possible effects on the Global Economy: A Theoretical Study. Financial Markets, Institutions and Risks, 3(4), 24- 31. http://doi.org/10.21272/fmir.3(4).24- 31.2019.

11. Jiang, Yu., Wang, G. (2017). Monetary Policy Surprises and the Responses of Asset Prices: An Event Study Analysis. SocioEconomic Challenges, 1(3), 22- 44. DOI: 10.21272/sec.1(3).22- 44.2017

12. Kyrychok, T. (2013). Alhorytm rozviazannia bahatokryterialnoi zadachi vyboru pokaznyka znoshuvannia banknot za dopomohoiu funktsii korysnosti [Algorithm for solving multicriteria problem of banknote wear rate selection using utility function]. Scientific news of NTUU «KPI», 1(87), 68- 75. Retrieved from https://ela.kpi.ua/handle/123456789/7076. [in Ukrainian]

13. Karminskiy, A. M., \& Zhdanova, O. P. (2013). Sovremennyie tendentsii bankovskih innovatsiy [Current trends of banking innovations]. Marketing and Management of Innovations, (2), 106- 118. URL: https://mmi.fem.sumdu.edu.ua/en/journals/2013/2/106- 118 [in Russian]

14. Levchenko, V., Boyko, A., Dotsenko, T. (2018). Otsiniuvannia zbytkiv bankiv vid yikh zaluchennia do protsesu lehalizatsii kryminalnykh dokhodiv [Assessment of banks' losses from their involvement 
Serhii V. Lyeonov, Olha V. Kuzmenko, Serhii V. Mynenko, Aleksy S. Kwilinski, Oleksii V. Lyulyov. Determining the Rating of Ukrainian Banks on the Risk of Legalization of Illegally Obtained Income

in the process of legalization of criminal proceeds]. Scientific journal «Black Sea Economic Studies», 35(2), 22-27. Retrieved from http://bses.in.ua/journals/2018/35_2_2018/6.pdf. [in Ukrainian]

15. Liubkina, O., Murovana, T., Magomedova A., Siskos, E. \& Akimova, L. (2019). Financial Instruments of Stimulating Innovative Activities of Enterprises and Their Improvements. Marketing and Management of Innovations, 4, 336- 352. http://doi.org/10.21272/mmi.2019.4- 26

16. Mehdi B. (2018). Financial stability and Solvency of Algerian banks, application of stress tests from 2012 to 2016. Financial Markets, Institutions and Risks, 2(4), 57- 67. DOI: http://doi.org/10.21272/fmir.2(4).57-67.2018

17. Molotok, I. (2020). Analysis Of The Relevance Of Fiscal Decentralization In Ensuring Country $\begin{array}{llll}\text { Investment } \quad \text { Attractiveness. SocioEconomic Challenges, } & 4(2), \quad 99-\end{array}$ https://doi.org/10.21272/sec.4(2).99- 105.2020.

18. Molotok, I.F. (2020). Bibliometric and Trend Analysis of Budget Transparency. Business Ethics and Leadership, 4(2), 116- 122. https://doi.org/10.21272/bel.4(2).116- 122.2020.

19. Naheem, M. (2016). Risk of money laundering in the US: HSBC case study. Journal of Money Laundering Control, 19(3), 225- 237. https://doi.org/10.1108/JMLC- 01- 2015- 0003.

20. Pomianek, I. (2018). Historical and Contemporary Approaches to Entrepreneurship. Review of Polish Literature. Business Ethics and Leadership, 2(2), 74- 83. DOI: 10.21272/bel.2(2).74- 83.2018.

21. Posokhov, I. M. (2013). Analiz doslidzhen zarubizhnykh naukovykh shkil ryzyk- menedzhmentu [Analysis of foreign schools of risk management]. Marketing and Management of Innovations, (4), 164- 172. https://mmi.fem.sumdu.edu.ua/en/journals/2013/4/164- 172. [in Ukrainian]

22. Riccardi, M., Milani, R., Camerini, D. (2019). Assessing Money Laundering Risk across Regions. An Application in Italy. Eur J Crim Policy Res, 25, 21- 43. https://doi.org/10.1007/s10610- 018- 9399- 9.

23. Subeh, M. A., Boiko, A. (2017). Modeling efficiency of the State Financial Monitoring Service in the context of counteraction to money laundering and terrorism financing. SocioEconomic Challenges, 1(2), 39- 51. http://doi.org/10.21272/sec.1(2).39- 51.2017.

24. Stavrova, E. (2019). The Lobbying in Post- communist Time: Bulgarian Case. Business Ethics and Leadership, 3(2), 18- 28. http://doi.org/10.21272/bel.3(2).18- 28.2019.

25. The State Financial Monitoring Service of Ukraine (2020). Statystychni dani shchodo otrymanykh Derzhfinmonitorynhom povidomlen pro finansovi operatsii protiahom II kvartalu 2020 roku [Statistics on notifications of financial transactions received by the SCFM during the second quarter of 2020]. Retrieved

from https://fiu.gov.ua/assets/userfiles/310/\%D0\%A1\%D1\%82\%D0\%B0\%D1\%82\%D0\%B8\%D1\%81\%D 1\%82\%D0\%B8\%D0\%BA\%D0\%B0/2020/IIkv_2020.pdf. [in Ukrainian]

26. United Nations Office on Drugs and Crime (2020). Money- Laundering and Globalization. Retrieved from https://www.unodc.org/unodc/en/money- laundering/globalization.html.

27. Utkina, O. (2019). Systema upravlinnia bankivskymy ryzykamy lehalizatsii dokhodiv, otrymanykh zlochynnym shliakhom [Bank risk management system for money laundering]. (PhD thesis). State Higher Educational Institution «University of Banking», Kyiv. Retrieved from http://ubs.edu.ua/images/PDF/Vidguk/utkina_money_laundering_DIS.pdf. [in Ukrainian]

28. Vasylieva, T., Harust, Yu., Vynnychenko, N., \& Vysochyna, A. (2018). Optimization of the financial decentralization level as an instrument for the country's innovative economic development regulation. Marketing and Management of Innovations, 4, 381- 390. http://doi.org/10.21272/mmi.2018.4- 33

29. Zolkover, A., Terziev, V. (2020). The Shadow Economy: A Bibliometric Analysis. Business Ethics and Leadership, 4(3), 107- 118. https://doi.org/10.21272/bel.4(3).107- 118.2020.

Manuscript received 15 September 2020 
С. В. Лсонов, О. В. Кузьменко, С. В. Миненко, О. С. Квілінський, О. В. Люльов.

Визначення рейтингу банків України за ризиком легалізації доходів, отриманих незаконним шляхом

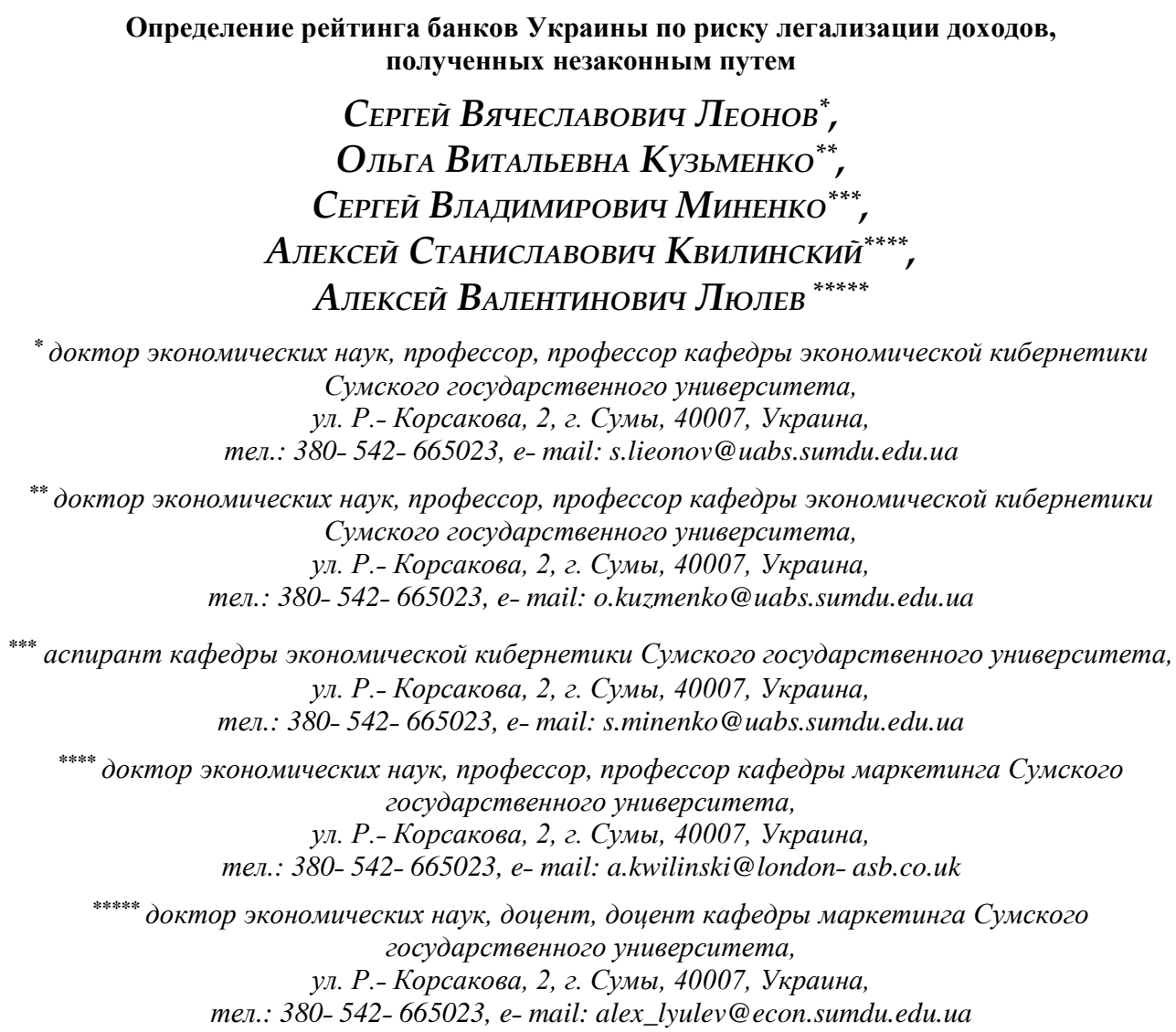

*** аспирант кафедры экономической кибернетики Сумского государственного университета, ул. Р.- Корсакова, 2, г. Сумы, 40007, Украина, тел.: 380-542-665023, e-mail: s.minenko@uabs.sumdu.edu.ua

**** доктор экономических наук, профессор, профессор кафедры маркетинга Сумского государственного университета.

ул. Р.- Корсакова, 2, г. Сумы, 40007, Украина,

тел.: 380- 542-665023, e-mail: a.kwilinski@london-asb.co.uk

***** доктор экономических наук, доцент, дочент кафедры маркетинга Сумского

государственного университета,

ул. Р.- Корсакова, 2, г. Сумы, 40007, Украина,

тел.: 380-542-665023, e-mail: alex_lyulev@econ.sumdu.edu.ua

В статье рассмотрен научно- методический подход к рейтинговани. банков по риску легализации доходов, полученных незаконным путем. Сформирована выборка из 18- ти показателей деятельности 65- ти банков Украины в 2019 году. Рассматриваются относительные показатели, характеризующие риск использования операций банка для легализации доходов, полученных незаконным путем. Логично показатели разделены на три части. Первая группа показателей характеризует количество и качество соблюдения банком действующего законодательства Украины в сфере финансового мониторинга. Вторая группа показателей отражают размеры оборота наличных в банке, что является характеристикой участия банка как конвертационного центра. Третья группа показателей характеризует привлечения банка в международные циклы отмывания доходов, учитывая транзакции в страны - оффшорные зоны и сомнительные операции без явного подтверждения с помощью внешнеэкономического контракта. Проведено исследование входных данных на мультиколинеарнисть, на основе чего исключено 5 показателей, которые являются коллинеарными с другими. Проведено нормализацию входного массива данных на основе нелинейной нормализации. Рассчитано весовые коэффициенты влияния каждого показателя на основе метода главных компонент. Определены оптимальное количество факторов на основе процента объяснимо дисперсии каждым фактором и графика каменистой осыпи. Для построения интегрального показателя применено метрику Минковского. На основе интегрального показателя сформирован рейтинг банков по риску легализации средств, полученных незаконным путем. С помощью вербально- числовой шкалы Харрингтона было предоставлено качественную характеристику риска использования операций банков для легализации незаконных доходов. Для проведения расчетов были использованы программное обеспечение MS Office Excel и инструментарий Correlations статистического пакета STATISTICA 10. 
Serhii V. Lyeonov, Olha V. Kuzmenko, Serhii V. Mynenko, Aleksy S. Kwilinski, Oleksii V. Lyulyov. Determining the Rating of Ukrainian Banks on the Risk of Legalization of Illegally Obtained Income

Ключевые слова: противодействие легализации незаконных доходов, рейтингования банков, риск легализации интегральный показатель, метрика Минковского.

\author{
Mechanism of Economic Regulation, 2020, No 3, 31-45 \\ ISSN 1726- 8699 (print)
}

Визначення рейтингу банків України за ризиком легалізації доходів, отриманих незаконним шляхом

\title{
СЕРГІй В'яЧЕСЛАВОВИЧ ЛєОНОВ*, ОЛЬГА ВІТАЛЇ̈ВНА КУЗЬМЕНКО ${ }^{* *}$, СЕРГІй ВОЛОДИМИРОВИЧ МИНЕНКО ${ }^{* * *}$, ОЛЕКСІй СТАНІСЛАВОВИЧ КВІЛІНСЬКИЙ ${ }^{* * * *}$, ОЛЕКСІЙ ВАЛЕНТИНОВИч ЛюЛЬОВ ${ }^{* * * * *}$
}

\author{
* доктор економічних наук, професор, професор кафедри економічної кібернетики \\ Сумського державного університету, \\ вул. Р.- Корсакова, 2, м. Суми, 40007, Украӥна, \\ тел.: 380-542-665023, e-mail: s.lieonov@uabs.sumdu.edu.ua \\ ** доктор економічних наук, професор, професор кафедри економічної кібернетики \\ Сумського державного університету, \\ вул. Р.- Корсакова, 2, м. Суми, 40007, Украӥна, \\ тел.: 380-542-665023, e-mail: o.kuzmenko@uabs.sumdu.edu.ua \\ *** аспірант кафедри економічної кібернетики Сумського державного університету, \\ вул. Р.- Корсакова, 2, м. Суми, 40007, Україна, \\ тел.: 380-542-665023, e-mail: s.minenko@uabs.sumdu.edu.ua \\ **** доктор економічних наук, професор, професор кафедри маркетингу \\ Сумського державного університету, \\ вул. Р.- Корсакова, 2, м. Суми, 40007, Украӥна, \\ тел.: 380-542-665023, e-mail: a.kwilinski@london-asb.co.uk \\ ***** доктор економічних наук, доцент, доцент кафедри маркетингу \\ Сумського державного університету, \\ вул. Р.- Корсакова, 2, м. Суми, 40007, Украӥна, \\ тел.: 380-542-665023, e-mail: alex_lyulev@econ.sumdu.edu.ua
}

\begin{abstract}
У статті розглянуто науково- методичний підхід до рейтингування банків за ризиком легалізації доходів, отриманих незаконним шляхом. Сформовано вибірку з 18- ти показників діяльності 65- ти банків України у 2019 році. Розглядаються відносні показники, які характеризують ризик використання операцій банку для легалізації доходів, отриманих незаконним шляхом. Логічно показники поділені на три частини. Перша група показників характеризують кількість і якість дотримання банком чинного законодавства України у сфері фінансового моніторингу. Друга група показників відображають розміри обороту готівки в банку, що є характеристикою участі банку як конвертаційного центру. Третя група показників характеризують залучення банку у міжнародні цикли відмивання доходів, враховуючи транзакції в країни - офшорні зони та сумнівні операції без явного підтвердження за допомогою зовнішньоекономічного контракту. Проведено дослідження вхідних даних на мультиколінеарність, на основі чого виключено 5 показників, які $є$ колінеарними 3 іншими. Проведено нормалізацію вхідного масиву даних на основі нелінійної нормалізації. Розраховано вагові коефіцієнти впливу кожного показника на основі методу головних компонент. Визначено оптимальну кількість факторів на основі відсотку пояснюваної дисперсії кожним фактором та графіку кам'янистого осипу. Для побудови інтегрального показника застосовано метрику Мінковського. На основі інтегрального показника сформовано рейтинг банків за ризиком легалізації коштів, отриманих незаконним шляхом. 3 допомогою вербально- числової шкали
\end{abstract}


С. В. Лсонов, О. В. Кузьменко, С. В. Миненко, О. С. Квілінський, О. В. Люльов.

Визначення рейтингу банків України за ризиком легалізації доходів, отриманих незаконним шляхом

Харрінгтона було надано якісну характеристику ризику використання операцій банків для легалізації незаконних доходів. Для проведення розрахунків було використано програмне забезпечення MS Office Excel та інструментарій Correlations статистичного пакету STATISTICA 10.

Ключові слова: протидія легалізації незаконних доходів, рейтингування банків, ризик легалізації інтегральний показник, метрика Мінковського.

JEL Codes: C01, C15, C58, G21

Table: 8; Figure: 1; References: 10

Language of the article: English

Лimepamypa

1. Bezhentseva, T., Aleksandrova, N., Matyus, E. (2018). Formation of system of indicators for evaluation of environmental activities. IOP Conference Series: Materials Science and Engineering, 451. https://doi.org/10.1088/1742- 6596/451/1/012182.

2. Бойко, А. (2019). Система протидії легалізації кримінальних доходів у забезпеченні економічної безпеки національної економіки. (Дис. д.е.н.). Сумський державний університет, Суми. Retrieved from https://essuir.sumdu.edu.ua/handle/123456789/75303.

3. Buriak An., Artemenko Al.. (2018). Reputation risk in banking: application for Ukraine. Financial Markets, Institutions and Risks, 2(2), 100-110. DOI: 10.21272/fmir.2(2).100- 110.2018

4. Cash, D. (2019). Sigma ratings: adapting the credit rating agency model for the anti- money laundering world. Journal of Money Laundering Control, 23(1), 1- 10. https://doi.org/10.1108/JMLC- 06- 20190046.

5. Dmytrov, S., Medvid, T. (2017). An approach to the use of indices- based analysis subject to money laundering and terrorist financing national risk assessment SocioEconomic Challenges, 1(1), 35- 47. http://doi.org/10.21272/sec.2017.1- 04.

6. Druhov, O., Druhova, V., Pakhnenko, O. (2019). The Influence of Financial Innovations on EU Countries Banking Systems Development. Marketing and Management of Innovations, 3, 167- 177. http://doi.org/10.21272/mmi.2019.3- 13

7. Dudchenko, V. (2020). Role of Central Bank Independence in Banking and Financial Stability Ensuring. Financial Markets, Institutions and Risks, 4(2), 115- 121. https://doi.org/10.21272/fmir.4(2).115- 121.2020.

8. Giebe, C., Hammerström, L., Zwerenz, D. (2019). Big Data \& Analytics as a sustainable Customer Loyalty Instrument in Banking and Finance. Financial Markets, Institutions and Risks, 3(4), 74- 88. http://doi.org/10.21272/fmir.3(4).74- 88.2019.

9. Goncharenko, T., Lopa L. (2020). Balance Between Risk And Profit In The Context Of Strategic Management: The Case Of Ukrainian Banks. SocioEconomic Challenges, 4(1), 111- 121. http://doi.org/10.21272/sec.4(1).111-121.2020.

10. Islam, S.T., Khan, M.Y.H. (2019). Evaluating the changes in the European Banking Regulation MiFID and its possible effects on the Global Economy: A Theoretical Study. Financial Markets, Institutions and Risks, 3(4), 24- 31. http://doi.org/10.21272/fmir.3(4).24- 31.2019.

11. Jiang, Yu., Wang, G. (2017). Monetary Policy Surprises and the Responses of Asset Prices: An Event Study Analysis. SocioEconomic Challenges, 1(3), 22- 44. DOI: 10.21272/sec.1(3).22- 44.2017

12. Киричок, Т. (2013). Алгоритм розв'язання багатокритеріальної задачі вибору показника зношування банкнот за допомогою функції корисності. Наукові вісті НТУУ «КПI», 1(87), 6875. Retrieved from https://ela.kpi.ua/handle/123456789/7076.

13. Карминский, А. М., \& Жданова, О. Р. (2013). Современные тенденции банковских инноваций. Маркетинг $i$ менеджмент інновацій, (2), 106- $118 . \quad$ URL: https://mmi.fem.sumdu.edu.ua/en/journals/2013/2/106-118.

14. Левченко В., Бойко А., Доценко Т. (2018). Оцінювання збитків банків від їх залучення до процесу легалізації кримінальних доходів. Науковий журнал «Причорноморські економічні cmydiï», 35(2), 22-27. Retrieved from http://bses.in.ua/journals/2018/35_2_2018/6.pdf.

15. Liubkina, O., Murovana, T., Magomedova A., Siskos, E. \& Akimova, L. (2019). Financial Instruments of Stimulating Innovative Activities of Enterprises and Their Improvements. Marketing and Management of Innovations, 4, 336- 352. http://doi.org/10.21272/mmi.2019.4- 26 
Serhii V. Lyeonov, Olha V. Kuzmenko, Serhii V. Mynenko, Aleksy S. Kwilinski, Oleksii V. Lyulyov. Determining the Rating of Ukrainian Banks on the Risk of Legalization of Illegally Obtained Income

16. Mehdi B. (2018). Financial stability and Solvency of Algerian banks, application of stress tests from 2012 to 2016. Financial Markets, Institutions and Risks, 2(4), 57- 67.

DOI: http://doi.org/10.21272/fmir.2(4).57- 67.2018

17. Molotok, I. (2020). Analysis Of The Relevance Of Fiscal Decentralization In Ensuring Country $\begin{array}{lllll}\text { Investment } \quad \text { Attractiveness. SocioEconomic } \quad \text { Challenges, } & 4(2), \quad 99- & 105 .\end{array}$ https://doi.org/10.21272/sec.4(2).99- 105.2020.

18. Molotok, I.F. (2020). Bibliometric and Trend Analysis of Budget Transparency. Business Ethics and Leadership, 4(2), 116- 122. https://doi.org/10.21272/bel.4(2).116- 122.2020.

19. Naheem, M. (2016). Risk of money laundering in the US: HSBC case study. Journal of Money Laundering Control, 19(3), 225- 237. https://doi.org/10.1108/JMLC- 01- 2015- 0003.

20. Pomianek, I. (2018). Historical and Contemporary Approaches to Entrepreneurship. Review of Polish Literature. Business Ethics and Leadership, 2(2), 74- 83. DOI: 10.21272/bel.2(2).74- 83.2018.

21. Посохов, I. М. (2013). Аналіз досліджень зарубіжних наукових шкіл ризик- менеджменту. $\begin{array}{llllll}\text { Маркетинг } \quad i \quad \text { менеджмент } & 172 .\end{array}$ https://mmi.fem.sumdu.edu.ua/en/journals/2013/4/164- 172

22. Riccardi, M., Milani, R., Camerini, D. (2019). Assessing Money Laundering Risk across Regions. An Application in Italy. Eur J Crim Policy Res, 25, 21- 43. https://doi.org/10.1007/s10610- 018- 9399- 9.

23. Subeh, M. A., Boiko, A. (2017). Modeling efficiency of the State Financial Monitoring Service in the context of counteraction to money laundering and terrorism financing. SocioEconomic Challenges, 1(2), 39- 51. http://doi.org/10.21272/sec.1(2).39- 51.2017.

24. Stavrova, E. (2019). The Lobbying in Post- communist Time: Bulgarian Case. Business Ethics and Leadership, 3(2), 18- 28. http://doi.org/10.21272/bel.3(2).18- 28.2019.

25. Державна служба фінансового моніторингу України (2020). Статистичні дані щодо отриманих Держфінмоніторингом повідомлень про фінансові операції протягом II кварталу 2020 року. Retrieved

from https:/fiu.gov.ua/assets/userfiles/310/\%D0\%A1\%D1\%82\%D0\%B0\%D1\%82\%D0\%B8\%D1\%81\%D 1\%82\%D0\%B8\%D0\%BA\%D0\%B0/2020/IIkv_2020.pdf.

26. United Nations Office on Drugs and Crime (2020). Money- Laundering and Globalization. Retrieved from https://www.unodc.org/unodc/en/money- laundering/globalization.html.

27. Utki Уткіна, О. (2019). Система управління банківськими ризиками легалізації доходів, отриманих злочинним шляхом. (Дис. канд. екон. наук). Державний вищий навчальний заклад «Університет банківської справи», Київ. Retrieved from http://ubs.edu.ua/images/PDF/Vidguk/utkina_money_laundering_DIS.pdf.

28. Vasylieva, T., Harust, Yu., Vynnychenko, N., \& Vysochyna, A. (2018). Optimization of the financial decentralization level as an instrument for the country's innovative economic development regulation. Marketing and Management of Innovations, 4, 381- 390. http://doi.org/10.21272/mmi.2018.4- 33

29. Zolkover, A., Terziev, V. (2020). The Shadow Economy: A Bibliometric Analysis. Business Ethics and Leadership, 4(3), 107- 118. https://doi.org/10.21272/bel.4(3).107- 118.2020. 